\title{
Launching workshop of PAGES' working group LandCover6k
}

\author{
Marie-José Gaillard'1, A.-M. Lézine ${ }^{2}$, K. Morrison ${ }^{3}$ and LandCover6k Steering Group ${ }^{4}$
}

Paris, France, 18-20 February 2015

The goal of PAGES' new LandCover6k Working Group is to achieve Holocene landcover and land-use reconstructions that can be used to evaluate and improve the scenarios of anthropogenic land-cover change (ALCC) by Klein Goldewijk et al. (2011; HYDE) and Kaplan et al. (2009; KK) for the purpose of climate modeling studies (Gaillard et al. 2015). Land Cover6k focuses on the last 6000 calendar years, i.e. the period in the Holocene when anthropogenic deforestation occurred in most continents, but it will also cover older periods in regions where significant human impact on vegetation occurred earlier. LandCover6k has links to other research programs, in particular IHOPE (Intergrated History and Future of People on Earth), GLP (Global Land Project), PMIP (Palaeoclimate Modelling Intercomparison Project), and PAGES' GPWG (Global Paleofire Working Group).

This workshop was attended by 50 participants from 17 countries. Its purpose was to summarize the state of the art in land cover studies in the Americas, Europe, Africa, Asia, and Oceania, and to discuss the working group's strategy for achieving its goals. The first part of the workshop was devoted to lectures and discussions on (i) the problems related to current descriptions of past land cover in climate modeling studies, (ii) the ALCC scenarios, (iii) the methods used to reconstruct past land use and land cover, (iv) the status of the pollen databases, and ( $v$ ) existing land-use and land-cover reconstructions. The second part of the workshop was devoted to organizing the working group, planning the strategy, and creating a timeline for the first three-year phase, including the next workshops and scientific products.

The participants decided that the LandCover6k research activities would be divided into two major areas, Land Cover, coordinated by Marie-José Gaillard, and Land Use, coordinated by Kathleen Morrison. Furthermore, the group is divided into nine subgroups each with one or several coordinators. The nine subgroups are (1) N America, (2) Latin America, (3) Europe, (4) Africa, (5) Asia, Australia, Oceania, (6) Land use (from archeological and historical data), (7) Methodology focused on the tropics, (8) Anthropogenic Land Cover Change (ALCC) modeling (i.e. revision of the ALCC scenarios KK and HYDE), and (9) Pollen productivity estimates (PPE).

LandCover6k will first focus on three time windows, $6000 \mathrm{BP}, 450 \mathrm{BP}$, and $100 \mathrm{BP}$, as an intermediate product to test the methods and strategies. Additional time windows will

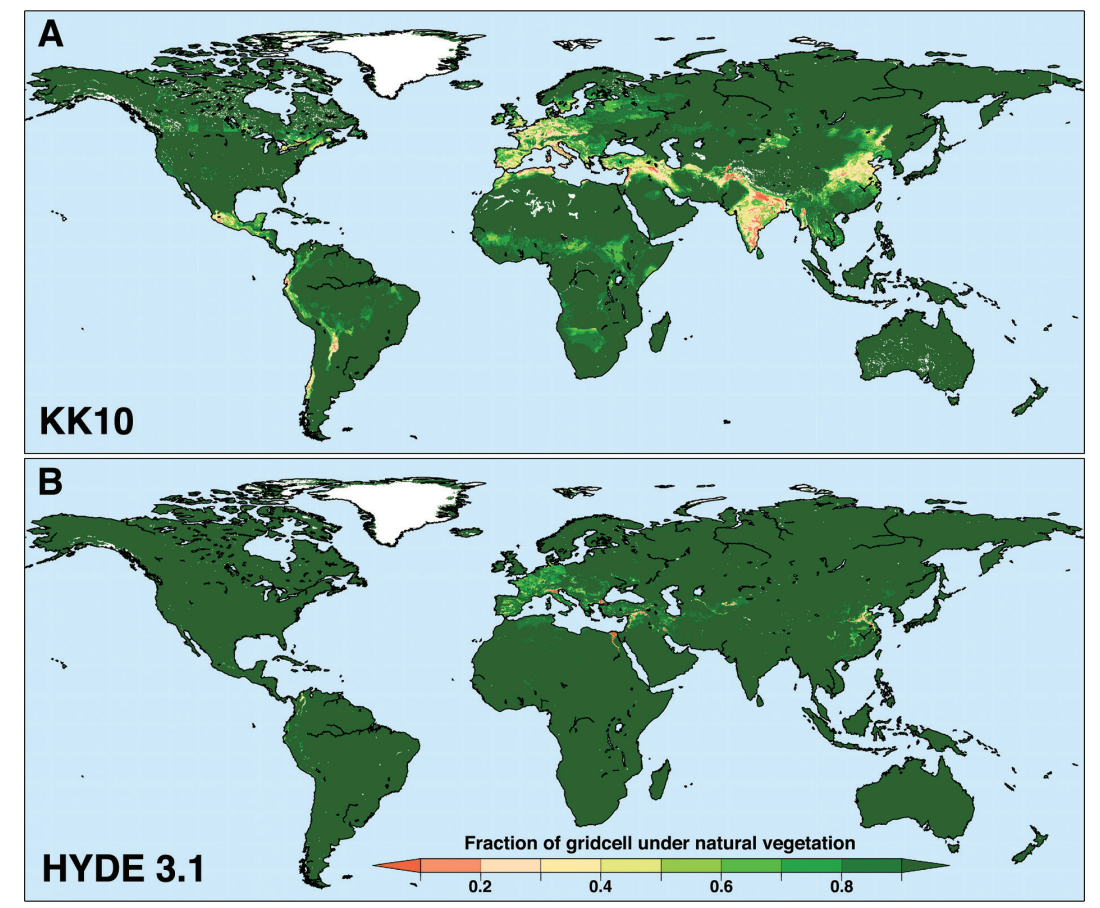

Figure 1: A comparison of human land use estimates (fraction of deforestation) around AD 1 from (A) the KK10 scenario (Kaplan et al. 2009) and (B) HYDE 3.1 (Klein Goldewijk et al. 2010). LandCover6k aims to improve the $\mathrm{KK}$ and HYDE scenarios and decrease their discrepancies using land-use reconstructions based on archeological and historical data, and quantitative land-cover reconstructions based on pollen records (forested versus deforested land).

be added at the end of the first three-year phase. Reconstructions of past land use will be achieved mainly by the community of archeologists and historians, and will include the challenging effort of upscaling archeological and historical information into maps of past major land-use systems. Reconstructions of past land cover at the global spatial scale will be achieved using pollen data and various methods including the modern analogue approach (e.g. Blois et al. 2011), biomization (e.g. Fyfe et al. 2013) and the REVEALS model (e.g. Trondman et al. 2015).

Of the meetings planned at the February workshop, several have already happened, including a working and information meeting at INQUA 2015, Japan; a Land-Use workshop in October 2015 in Paris, France organized by Kathleen Morrison; a steering group meeting in November 2015; and a training workshop on pollen-based reconstructions of land cover in September 2015 in Reading, UK. There will be a Landcover6k sessions at AGU (2015) and EGU (2016). We also plan sessions at the International Congress of Palynology (IPC) in 2016, and at the next PAGES Open Science Meeting (OSM) in 2017, as well as a number of workshops in 2016.
Further details on the organization of the working group, coordinators and key participants, and future activities can be found on the LandCover6k website: www.pages-igbp. org/ini/wg/landcover6k.

\section{AFFILIATIONS}

'Biology and Environmental Science, Linnaeus

University, Kalmar, Sweden

${ }^{2}$ LOCEAN, Pierre et Marie Curie University, Paris, France

${ }^{3}$ Anthropology, University of Chicago, USA ${ }^{4}$ www.pages-igbp.org/ini/wg/landcover6k/people

\section{CONTACT}

Marie-José Gaillard: marie-jose.gaillard-lemdahl@Inu.se REFERENCES

Blois JL et al. (2011) Quat Sci Rev 30: 1926-1939

Boyle JF et al. (2011) Holocene 21: 715-722

Fyfe R et al. (2013) Quat Sci Rev 73: 132-148

Gaillard MJ et al. (2015) PAGES Mag 23(1): 38-39

Klein Goldewijk K et al. (2011) Glob Ecol Biogeogr 20 : 73-86

Kaplan JO et al. (2009) Quat Sci Rev 28: 3016-3034

Trondman A-K et al. (2015) Glob Chang Biol 21: 676-697 